\title{
Investigating the Wound Healing Potential of Costus afer (Ker Gawl) Stem Juice on Cutaneous Wounds of Albino Rats
}

\author{
Kudighe Patrick Udoh ${ }^{1 *}$, Akpan Udo Ekanem ${ }^{2}$ and Aniekan Imo Peter ${ }^{2}$ \\ ${ }^{1}$ Community Health Officers Training School, University of Uyo Teaching Hospital, Akwa Ibom, Nigeria \\ ${ }^{2}$ Department of Anatomy, University of Uyo, Akwa Ibom, Nigeria
}

"Corresponding author: Kudighe Patrick Udoh, Community Health Officers Training School, University of Uyo Teaching Hospital, Uyo, Nigeria, E-mail: kudigheudoh@gmail.com

Received: 27 Mar, 2018 | Accepted: 26 Jun, 2018 | Published: 02 Jul, 2018

Citation: Udoh KP, Ekanem AU, Peter Al (2018) Investigating the Wound Healing Potential of Costus afer (Ker Gawl) Stem Juice on Cutaneous Wounds of Albino Rats. Cell Stem Cells Regen Med 3(2): dx.doi. org/10.16966/2472-6990.118

Copyright: ( 2018 Udoh KP, et al. This is an open-access article distributed under the terms of the Creative Commons Attribution License, which permits unrestricted use, distribution, and reproduction in any medium, provided the original author and source are credited.

\section{Abstract}

This study was carried out to investigate the healing potential of Costus afer stem juice extract on rat skin wound. Twenty-five (25) adult female albino rats weighing between 243-320g were used for the study. They were divided equally into 5 groups. The rats were aseptically wounded on their dorsum under ketamine hydrochloride anaesthesia. Immediately hemostasis was attained, the rats were treated according to their groups. Group A wounds were left without treatment, group B were treated only on the first day with iodine, group $C$ were treated for 7 days with iodine ointment, group $D$ were treated only on the first day with Costus afer stem juice extract, and group E were treated for 7 days with Costus afer stem juice extract. The rats were under observation for 35 days within which complete healing was observed. The time taken for the wounds to heal was recorded in days for each animals and ANOVA analysis was carried out using SPSS v. 20. On complete healing, sections of the healed tissue were collected for H\&E stain. During the healing process, it was observed that wounds treated with Costus afer stem juice extract maintained a moist wound environment without infection despite being open to the environment. The healing time was also found to be significantly small $(p<0.05)$ in group $D$ treated only on the first day with Costus afer stem juice extract. H\&E sections showed randomly organized dermal fibres in group D and $\mathrm{E}$ treated with Costus afer stem juice extract. There was also indication of growing hair follicles in group D treated only on the first day with Costus afer stem. In conclusion, Costus afer stem juice extract maintained a moist wound environment with more favorable healing outcome than iodine treatment.

Keywords: Moist wound healing; Costus afer stem; Regeneration of skin; Dermal organization

\section{Introduction}

The process of wound healing involves a complex cascade of cellular and biochemical mechanisms aiming at the restoration of the structural and functional integrity with regain of strength of the injured tissues or organs. It is brought about by cell-cell and cellmatrix interactions that signal the process through three overlapping phases of inflammation, proliferation and tissue remodeling [1,2].

The wound healing process has been found to be significantly enhanced in moisturized wounds than in dry wounds. The availability of growth factors is extended and the rate of cell migration is enhanced in moist wounds [3-6]. Moist wound environment enhances painless debridement of wounds by insulating and protecting nerve endings. In addition, it also provides a physiological environment that reduces scar formation and favors tissue regeneration [4,7]. Consequently, it has been suggested that an ideal wound management should aim to maintain a moist wound environment, while limiting loss of fluid, shield the wound from further damage, remove necrotic debris, promote granulation tissue formation, relieve pain and protect the wound from bacterial contamination $[3,6,7]$.

Major concerns of open moist wound have been dehydration of surrounding tissues and the possibility of microbial contamination of the wound. This has led to the use of occlusive and semi-occlusive dressings to keep the wound hydrated while limiting evaporation of tissue fluid $[3,7,8]$. However, occlusive dressings have been found to accumulate fluid and promote bacterial growth at wound sites. There is also ineffective barrier function recovery and damage to the new epidermis on removal of occlusive dressings. On the other hand, semi occlusive dressings have been found to provide the required moisture for the healing process to proceed normally without microbial growth $[9,10]$. According to Korting and colleagues [6], topical treatments that maintain moist wound environment may provide the most ideal management of minor cutaneous wounds. These treatments allow regular assessment of the wound without the risk of compromising the wound bed as required for proper wound management $[3,11]$. Several gel compounds such as hydrocolloid dressings and calcium alginate have been successfully used in this regard for wound management to maintain a moist wound environment $[7,9]$. However, these products are expensive and scarce in local health facilities.

Studies have shown that plants have immense potential in the management of wounds. They have been shown to fight infection, accelerate healing and induce regeneration of loss tissues [12]. Costus 
afer stem is used traditionally for the treatment of wounds [13]. Scientific investigations have shown that it contains biomolecules and minerals that have been found to significantly enhance wound healing $[14,15]$. Thus, this study was carried out to investigate the wound healing effect of Costus afer stem juice extract on cutaneous wound of adult albino rats.

\section{Methodology}

\section{Research design and ethical approval}

This study was conducted in the Experimental Laboratory of the Department of Anatomy, University of Uyo, Nigeria. The study consists of 5 groups of animals: a control group, 2 experimental groups and 2 standard groups. All animals were wounded on their dorsum to give an excision wound model. Animals in the control group were left without treatment, one experimental group was treated only on the first day with Costus afer stem juice extract, while the second experimental group was treated for seven days with Costus afer stem juice extract. The standard groups were treated with iodine ointment, one group only on the first day and the other group for seven days. Ethical approval for the study was duly obtained from the Ethical Committee of the Faculty of Basic Medical Sciences, University of Uyo, Nigeria.

\section{Plant collection and preparation of extract}

The Costus afer plant was identified and registered at the Herbarium of the Department of Pharmacognosy, Faculty of Pharmacy, University of Uyo with the number UUPH26(a) as identified by a plant taxonomist. The plant which grows wild was collected in February, 2017 from bushes within Uyo, Akwa Ibom State, Nigeria. The plant stem was washed with running water, cut into pieces and crushed with blender (NAKAI-Japan; HR-2818). The juice was obtained by squeezing the blended product in a chess cloth and the filtrate was concentrated in beakers placed in water bath at $40^{\circ} \mathrm{C}[16]$.

\section{Experimental protocol}

A total of 25 adult female albino rats weighing between 243-320g, were used for the study [17]. Equipment and the laboratory rooms were soaked overnight in antiseptic solution and washed with soapy water for asepsis. The rats were brought in after the antiseptic vapour had completely dissipated from the atmosphere of the room. The rats were divided equally into 5 groups of $\mathrm{A}, \mathrm{B}, \mathrm{C}, \mathrm{D}$, and $\mathrm{E}$ (Table 1 ). The rats were housed individually in rubber cages at temperature between $22-26^{\circ} \mathrm{C}$, humidity of $50-60 \%, 12$ hours light/dark lighting and fed with standard rat pelletized diet (Vital Feed Growers, Green Cereals Nigeria Ltd.) and water ad libitum. After one week of acclimatization, all the rats were wounded on their dorsum and treated according to their groups. Their health status was closely monitored by regular assessment of their weight and stress indicators according to National Centre for the Replacement, Refinement and Reduction (NC3Rs) of Animals in Research [18], as well as internationally accepted standard guide for care and use of laboratory animals promulgated and adopted by the National Institute of Health (NIH) publication number 85(23), revised 1996 and related ethics and regulation. After wounding, the rats were treated accordingly (Table 1) and observed for 35days during which all the wounds completely healed.

\section{Median lethal dose $\left(\mathrm{LD}_{50}\right)$ of Costus afer stem juice extract}

The $\mathrm{LD}_{50}$ of the stem juice extract was calculated using the upand-down method according to OECD [19]. Healthy adult female albino mice were used for the test. The mice were housed in cages at room temperature between $22-26^{\circ} \mathrm{C}, 50-60 \%$ humidity, and lighting of 12 hours light and 12 hours dark. They were fed with conventional rodent laboratory diets (Vital Feed Growers, Green Cereals Nigeria Ltd.) with unlimited supply of water. After 5 days of acclimatization, their feed was withdrawn for 4 hours and their fasted body weight was taken. A limiting dose of $5000 \mathrm{mg} / \mathrm{kg}$ body weight of the juice extract was administered orally to a mouse and observed for $48 \mathrm{hrs}$. Since no side effect was observed, additional 4 mice were administered sequentially and observed for another $48 \mathrm{hrs}$. The $\mathrm{LD}_{50}$ was considered to be higher than $5000 \mathrm{mg} / \mathrm{kg}$ body weight since no fatality or side effects were recorded for the animals studied.

\section{Phytochemical analysis}

A portion of the extract was analyzed for its phyto-components. Saponins, alkaloid, triterpene, tannins, flavonoids, phenols and cyanide were analysed qualitatively according to the procedure by Ekwueme et al. [20]. Flame photometry was used to determine the presence of potassium, while calcium, magnesium, copper, manganese, and phosphorus were detected using Atomic Absorption Spectroscopy (AAS) as described by Vogel [21].

\section{Wound creation}

The surgical procedure during wound creation was under high aseptic technique. All surgical instruments were sterilized by autoclaving at $138^{\circ} \mathrm{C}$ for 30 minutes. Throughout the wounding process, the rats were under anaesthesia with ketamine hydrochloride (Ketanir by Jawa International Nigeria Limited) at $120 \mathrm{mg} / \mathrm{kg}$ b.w. i.p. An electric clipper (model number GM-3005) was used to shave their dorsum. After cleaning the shaved area with an antiseptic and methylated spirit, a $1.5 \times 1.5 \mathrm{~cm}^{2}$ were marked off as the wounding site using methylene blue and the surgical site was draped. A full thickness square wound was excised from the target area using surgical blade, scissors and forceps, and haemostasis was attained by applying pressure on the wound using sterile gauze.

\section{Treatment of wounds}

In group $\mathrm{A}$, the wound was left to heal naturally without treatment. Groups B and C rats were treated with $0.2 \mathrm{ml}$ of Povidoneiodine ointment (Jawa International Nigeria Limited) at 5\%w/w concentration on the first day only and for 7 days, respectively. A semiliquid concentration of $4 \mathrm{~g} / \mathrm{ml}$ solution of Costus afer stem juice extract with water was used for the treatment of groups $\mathrm{D}$ and $\mathrm{E}$ wounds using $0.2 \mathrm{ml}$ on each application. Group D wounds were treated with the extract paste only on the first day, while group E were treated with the Costus afer paste daily for 7 days (Table 1).

\section{Healing time}

The time taken for the wound to completely heal was recorded for each animal and statistically analysed for each group.

Table 1: The experimental groups.

\begin{tabular}{|c|c|c|}
\hline Group & Number & Treatment \\
\hline A & 5 & Control \\
\hline B & 5 & lodine ointment for 1 day \\
\hline C & 5 & lodine ointment for 7 days \\
\hline D & 5 & Costus afer paste for 1 day \\
\hline E & 5 & Costus afer paste for 7 days \\
\hline
\end{tabular}




\section{Histological study}

The wound was considered to be completely healed when no visible blood vessel could be observed at the wound site. On complete healing; each rat was euthanized using chloroform inhalation in desiccator jar. Tissue samples were collected from the wound site to process for Haematoxylin and Eosin staining as described in Bancroft and Layton [22].

\section{Data analysis}

Data collected from the different groups of animals were expressed in mean \pm standard deviation. They were analysed with SPSS (version 20 ), using ANOVA with Tukey's and Dunnett's post hoc tests with the level of significance taken at $\mathrm{p}<0.05$.

\section{Results}

\section{Median lethal dose $\left(\mathrm{LD}_{50}\right)$ of Costus afer stem juice extract}

The $\mathrm{LD}_{50}$ of the extract was found to be higher than $5000 \mathrm{mg} / \mathrm{kg}$ body weight.

\section{Phytochemical analysis}

Phytochemical analysis showed that Costus afer stem juice extract contained biomolecules that have been found to promote wound healing, such as alkaloids, saponin, flavonoids, triterpene, quinones, lignans and stilbenes (Table 2). Biological minerals including potassium, sodium, calcium, magnesium, copper, manganese, phosphorus and potassium were also detected in the extract (Table 3).

\section{Wound site appearance}

The result of the study showed that Costus afer stem juice extract enhanced the healing process. The extract was also found to maintain a moist healing environment without any clinical sign of infection despite the wound being exposed to the atmosphere (Figures 1-3).

Table 2: Phytoconstituents of Costus afer stem juice extract.

\begin{tabular}{|c|c|}
\hline Test & Intensity \\
\hline Saponin & +++ \\
\hline Alkaloids & +++ \\
\hline Tannin & - \\
\hline Flavonoids & ++ \\
\hline Phenol & - \\
\hline Terpene (triterpene) & ++ \\
\hline Quinones & + \\
\hline Lignans & +++ \\
\hline Stilbenes & ++ \\
\hline
\end{tabular}

Table 3: Mineral content of Costus afer stem juice extract.

\begin{tabular}{|c|c|}
\hline Mineral & Detection \\
\hline Sodium & + \\
\hline Calcium & +++ \\
\hline Magnesium & +++ \\
\hline Copper & + \\
\hline Manganese & + \\
\hline Phosphorus & ++ \\
\hline Potassium & +++ \\
\hline
\end{tabular}

However, Group E wounds treated with the juice extract for seven days developed a thick hard scab with fibrous tissue formed at the wound site beneath the scab (Figures 1,2). After the scab fell off, the fibrous tissue was resorbed and the healing process progressed effectively in a moist environment (Figure 3). Rats in group D, treated only on the first day with Costus afer stem juice extract, had the highest weight gain but there was no significant difference across the groups (Table 4).

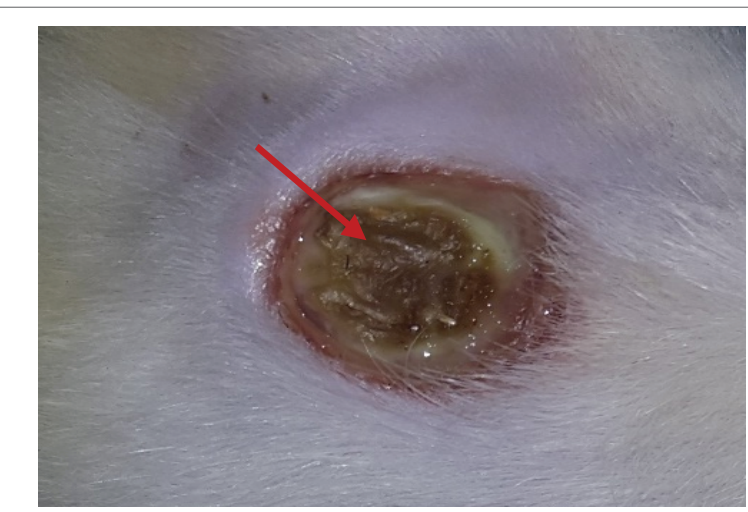

Figure 1: Wound site of group $E$ after the scab had fallen leaving an open wet wound. The red arrow shows the fibrous tissue that had formed beneath the scab.

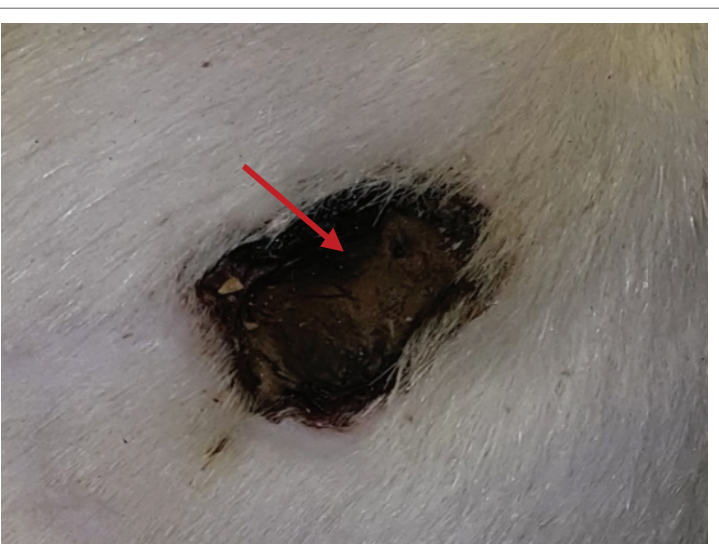

Figure 2: Thick scab (red arrow) formed from Costus afer application at wound site.

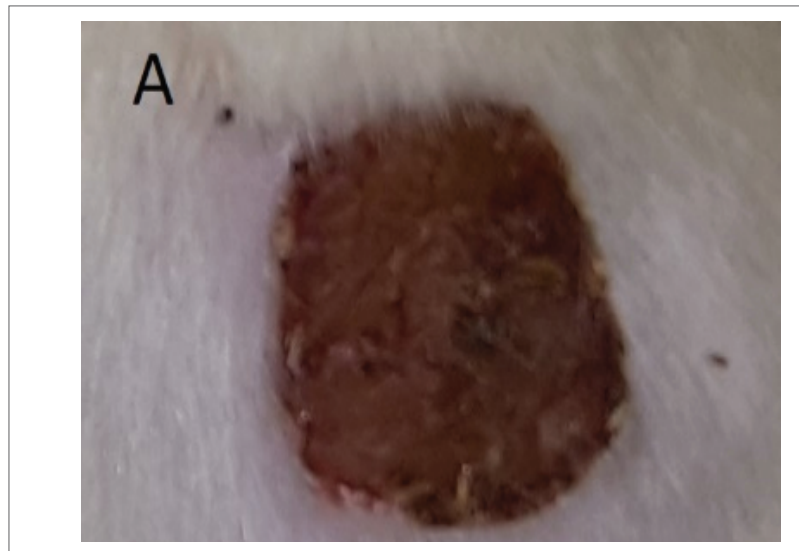

Figure 3: A: 5th day of wound left without treatment showing a dried wound surface. 


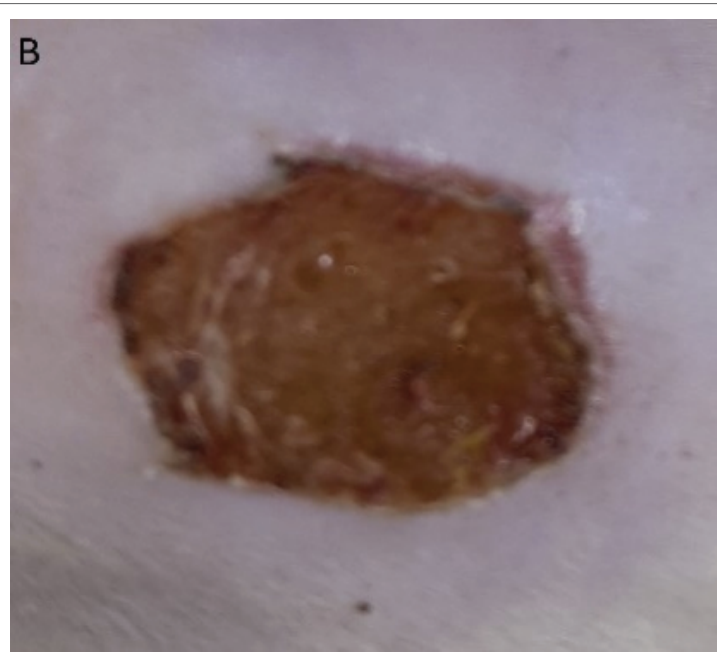

Figure 3: B: 5th day of wound treated only on the first day with iodine ointment showing a dried wound surface.

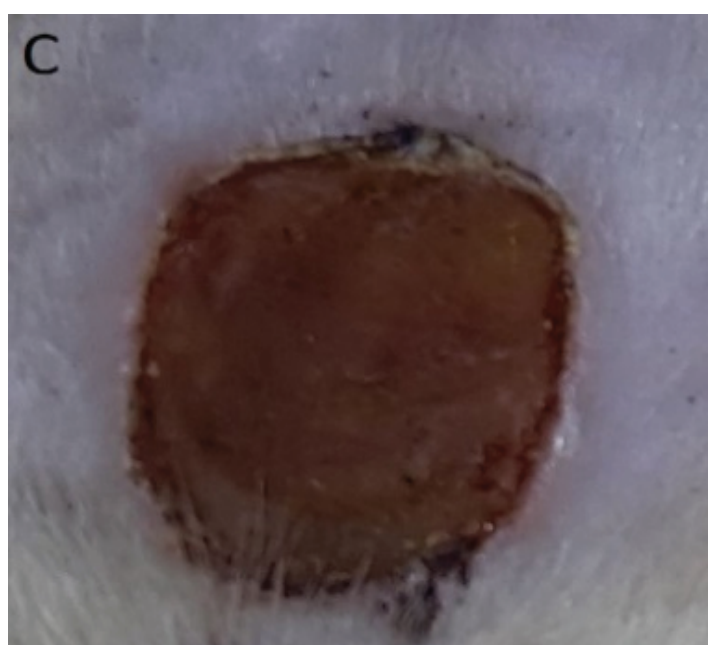

Figure 3: C: 5 th day of wound treated for 7 days with iodine ointment showing a dried wound surface.

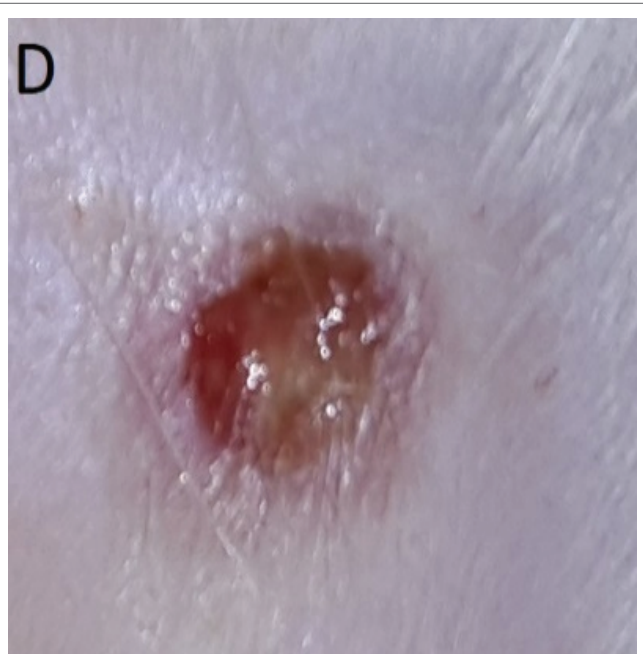

Figure 3: D: 5 th day after falling off of scab from wounds treated only on the first day with Costus afer stem juice extract. The wound surface is moist with advanced healing.

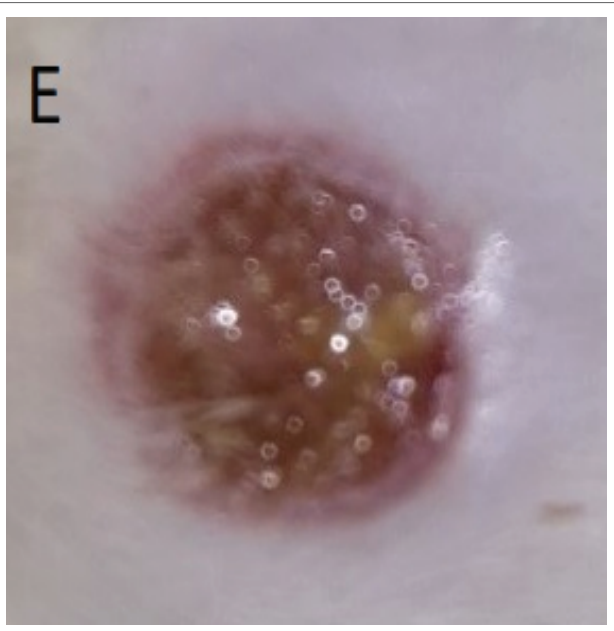

Figure 3: E: 5th day after falling off of scab from wounds treated only on the first day with Costus afer stem juice extract. The wound surface is moist with epithelialization advancing from the edges.

Table 4: Percentage change in weight of rat.

\begin{tabular}{|c|c|c|c|c|}
\hline Groups & Number & $\begin{array}{c}\text { Initial Weight } \\
\text { (g) }\end{array}$ & $\begin{array}{c}\text { Final Weight } \\
\text { (g) }\end{array}$ & $\begin{array}{c}\text { Change in Weight } \\
\text { (\%) }\end{array}$ \\
\hline A & 5 & $280 \pm 4.9$ & $313 \pm 8.7$ & $18.4 \pm 4.03$ \\
\hline B & 5 & $278 \pm 14.1$ & $307 \pm 18.2$ & $16.6 \pm 2.79$ \\
\hline C & 5 & $268 \pm 21.6$ & $294 \pm 24.1$ & $16.0 \pm 4.06$ \\
\hline D & 5 & $288 \pm 9.6$ & $325 \pm 11.2$ & $20.0 \pm 2.00$ \\
\hline E & 5 & $272 \pm 13.4$ & $304 \pm 21.0$ & $18.8 \pm 4.81$ \\
\hline p-Value & & & & 0.991 \\
\hline
\end{tabular}

\section{Healing time}

The time taken for the wound to completely heal in Costus afer treated groups was calculated after the falling off of the scab. When analysed with the other groups, the healing time was found to be significantly reduced in Costus afer treated wounds (Figure 4 and Table 5).

\section{Histological study}

Hematoxilyn and eosin sections showed close and random organization of dermal fibres in Costus afer treated groups similar to the organization of normal uninjured tissue (Figures 5-7). Development of hair follicles were also observed in group D treated with Costus afer stem juice extract only on the first day. Groups A, B and $C$ showed basket weave organization of fibres running in the plane of the epidermis (Figures 8-10).

\section{Discussion}

Costus afer stem has been used traditionally for the treatment of several ailments including skin disorders, veneral diseases and colic. The stem decoction is widely used for treatment of various eye affections, rheumatism, cough, sore throat and other respiratory problems [23]. The sap is used for the treatment of malaria, jaundice and to prevent miscarriages $[13,24,25]$. When used for the treatment of wounds, the sap is said to be burning on open wounds with anodyne and healing effects $[13,23]$. Scientific investigations have shown that the stem extract of Costus afer has significant antibacterial, antifungal and amoebicidal activity in vitro [24,26,27]. Its antinociceptive and 


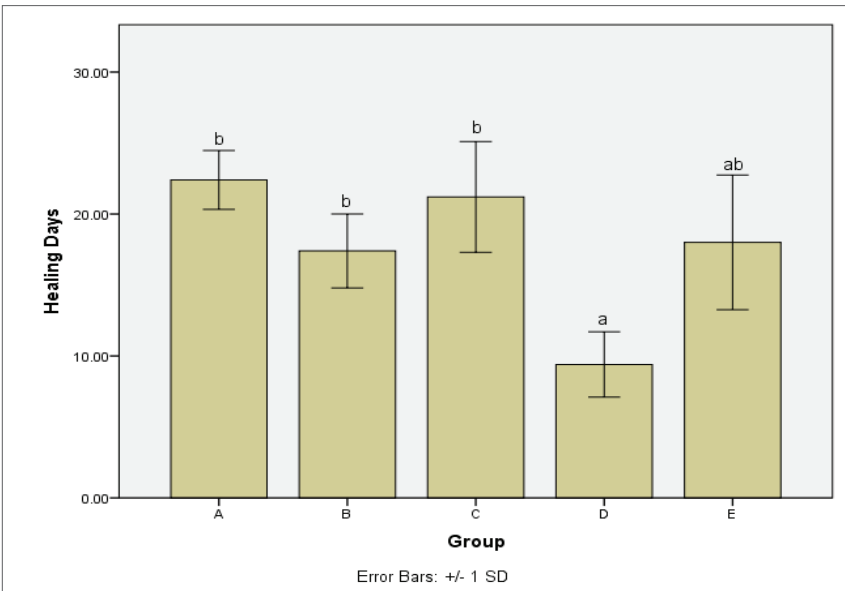

Figure 4: Days taken for the wound to heal completely in each experimental group. a,b: bars with different annotations are significantly different (ANOVA analysis with SPSS v. 20; $p=0.00$ ).

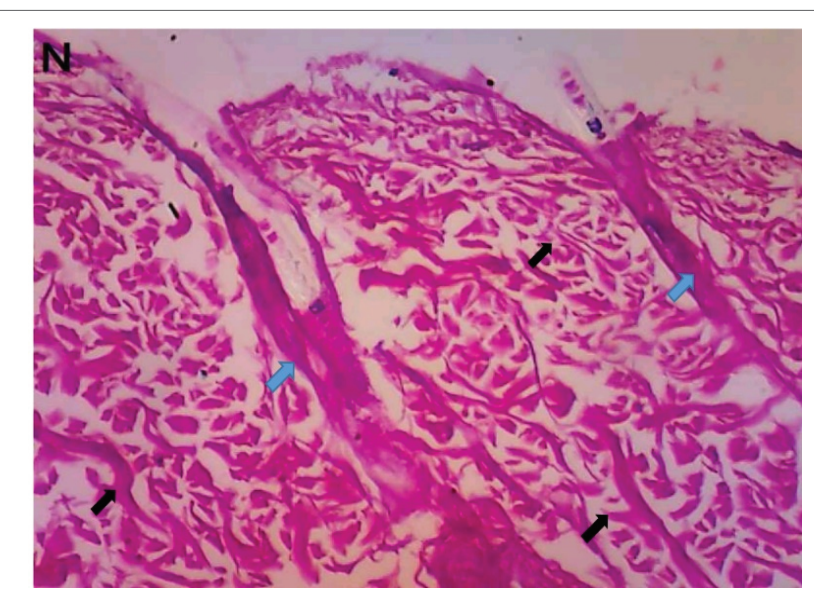

Figure 5: Normal dermal tissue with haphazard organization of collagen fibres (black arrows) from normal uninjured skin. Hair fibres are clearly visible (blue arrows) (H\&E × 100).

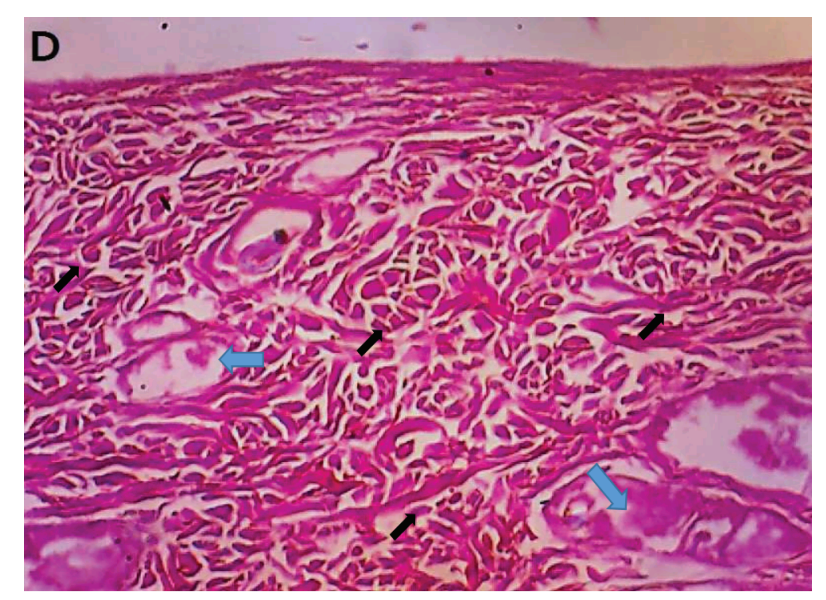

Figure 6: Healed dermal tissue from group D, treated with Costus afer extract only on the first day. The bundles are thick, tightly and randomly organized (black arrows). There are also growing hair follicles (blue arrows). (H\&E × 100).
Table 5: Duration of wound healing across the groups.

\begin{tabular}{|c|c|c|}
\hline Group & No. & Days \pm SD \\
\hline A & 5 & $22.4 \pm 2.07$ \\
\hline B & 5 & $17.4 \pm 2.60$ \\
\hline C & 5 & $21.2 \pm 3.89$ \\
\hline D & 5 & $9.4 \pm 2.30$ \\
\hline E & 5 & $18.0 \pm 4.74$ \\
\hline
\end{tabular}

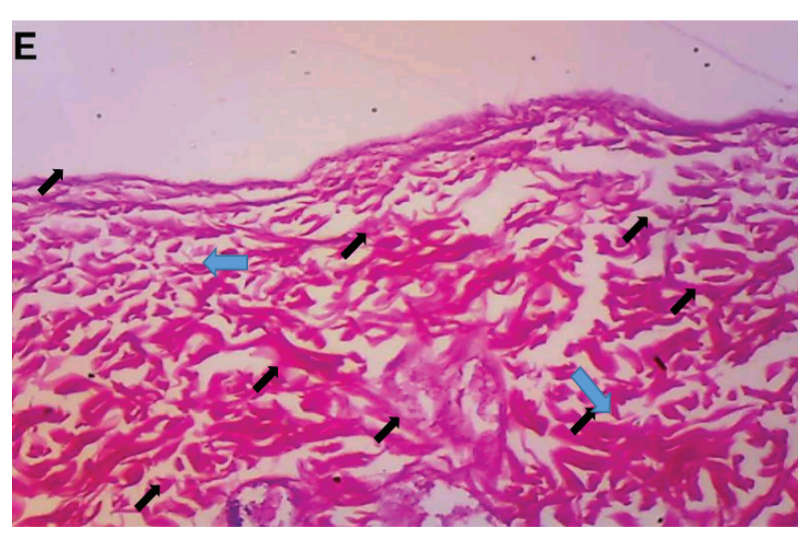

Figure 7: Healed dermal tissue from group E, treated with Costus afer extract for seven days. Fibres are thick and randomly organized (arrows) $(\mathrm{H \& E} \times 100)$.

antioxidant properties have also been reported [14,28]. The stem extract has also been reported to modulate lipid profile, reverse alcohol induced liver cirrhosis and alleviate hepatic oxidative stress and toxicity $[29,30]$. It has also been reported as a promising agent in the management of diabetes due to its ability to inhibit $\alpha$-amylase and a-glucosidase activities [31].

The result of the $\mathrm{LD}_{50}$ from this study showed that Costus afer stem juice extract can be considered safe at the dose used for the study. This is in agreement with previous studies which reported that the $\mathrm{LD}_{50}$ of Costus afer stem extract is greater than $5000 \mathrm{mg} / \mathrm{kg}$ body weight and its chronic consumption has no significant toxic effect on major tissues and organs of the body [16,32].

The ability of Costus afer stem juice extract to discharge copious exudate and maintain an open moist wound surface may be attributed to its biomolecules and mineral constituents. Alkaloids and flavonoids which are rich in the plant extract have been found to be potent vasodilators [33]. This property may have contributed to the copious extraction of tissue fluid on fresh application, and the maintenance of a moist wound environment through most of the healing process. The presence of lignans which are known to be platelet inhibitors may also contribute to this process by inhibiting clot formation [34]. This can be further explained by the observation that the original scab seemed to be dried residues of Costus afer stem juice extract, which thickens as more extract was applied.

Furthermore, the mineral components of the extract may have provided an ionic environment that favours extraction of tissue fluid and maintenance of moist wound environment. Sodium may have contributed by increasing the osmotic pressure of the wound environment, thus drawing fluid from surrounding tissues [35]. The flow of exudate could have been limited to the maintenance of a moist wound environment through the action of potassium and phosphorus in regulating fluid and acid-base balance [36,37]. Control 


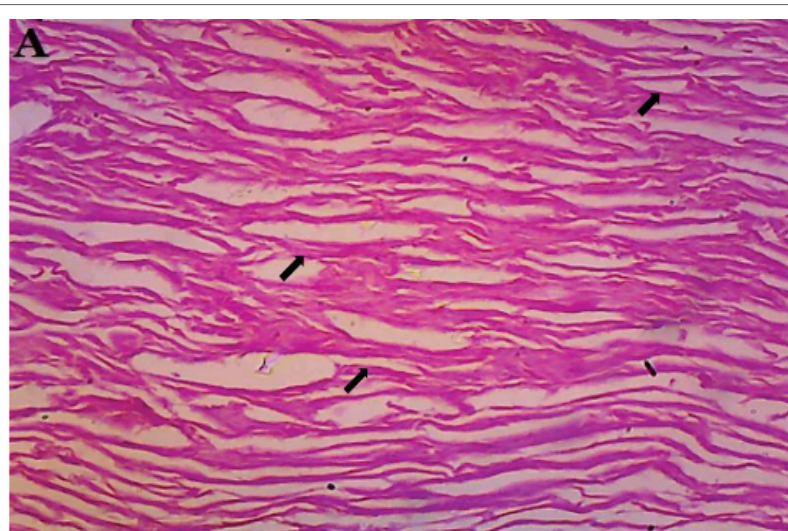

Figure 8: Healed dermal tissue with planar orientation of collagen fibres (arrows) from control (group A). The fibres are thin and run in parallel with few crosslinks (H\&E × 100).

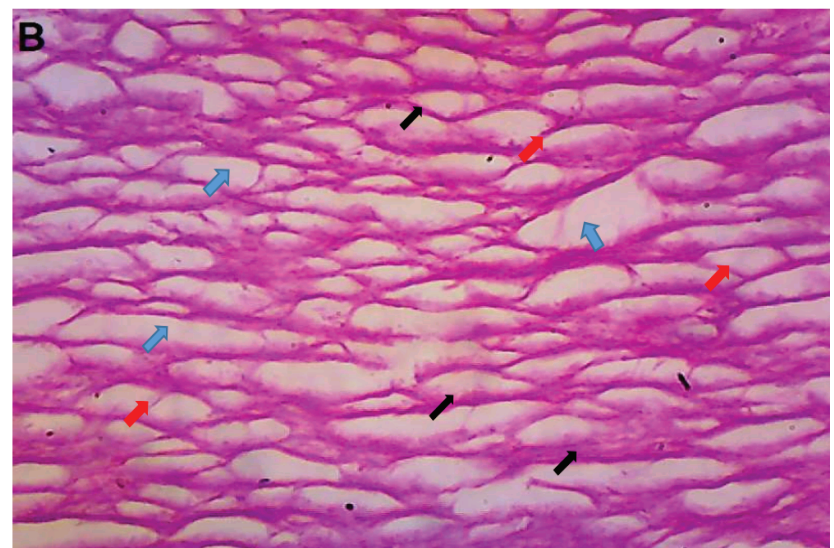

Figure 9: Healed dermal tissue with basket weave appearance of collagen fibres from group $B$, treated with iodine ointment only on the first day. The fibres are thin (black arrows) and have crosslinks (red arrows) that loosely interlace with wide spaces (blue arrows) $(H \& E \times 100)$.

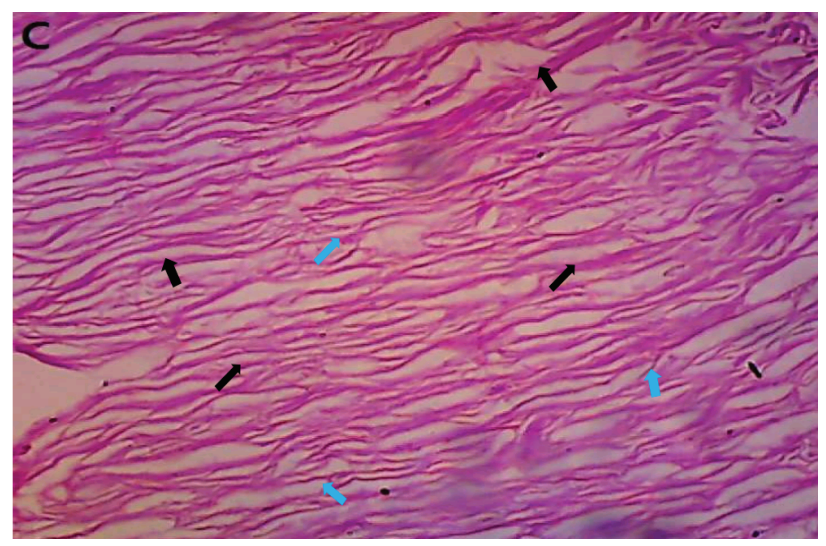

Figure 10: Healed dermal tissue from group $C$, treated with iodine ointment for seven days. The fibres are light and run closely in parallel direction (black arrows). There are fewer crosslinks (blue arrows) $(\mathrm{H} \& \mathrm{E} \times 100)$. of blood pressure and vessel contraction by magnesium could have counteracted the plausible effects of lignans and alkaloids to provide an optimum moist wound environment that promotes wound healing $[38,39]$.

The absence of infection on the open moist wound could be due to the activities of alkaloids, flavonoids, lignans, stilbenes, quinones and triterpenes. Each of these molecules has been reported to exhibit antiinflammatory, antimicrobial and antioxidative properties on wounds [34,40-42]. These properties may have also contributed to the lack of inflammation due to the attached thick scab, and resorption of the formed fibrous tissue after the scab fell off. It has been reported that copper plays a role in immune response and phagocytosis which could also be implied in this process [43].

Moist wound environment has been shown to be an optimum requirement for ideal wound management. It has been found to significantly enhance healing process by preserving growth factors and enzymes at wound site and speeding up the rate of cell migration compared to dry wound surface $[3,4,6]$. This process may have contributed to the significantly lower healing time observed in group $\mathrm{D}$, treated only on the first day with Costus afer paste. Even with the complication of fibrous tissue formation in group E treated for 7 days with Costus afer paste, the healing time was not significantly higher than the other groups. Being open to the environment, atmospheric oxygen gets absorbed into the moist wound surface. Thus providing additional source of oxygen for wound cells especially fibroblasts and neutrophils, of which their activities are highly oxygen dependent $[8,10,44]$. This high oxygen tension provided by the open moist wound may have enhanced the resorption of the initial fibrous tissue formed beneath the intact scab by promoting the activity of neutrophils and macrophages while inhibiting the activity and proliferation of fibroblasts to a level that does not totally compromise the healing process $[2,45]$. This could be advantageous in enhancing the healing of wounds that have impaired arterial oxygen supply, such as diabetic foot ulcers $[8,10]$.

The copious flow of wound exudate at first application of the extract may contribute to reduced healing time by bringing wound cells and molecules to the wound site, thereby bypassing the migratory time of the cells and initiating immediate healing activity $[4,10]$. Moreover, the open moist wound from Costus afer treatment seems to have been controlled against dehydration as there was no significant difference in the percentage change in weight between the groups, the tissues around the wound site appeared viable, and the rats remained active throughout the experimental process [46]. To the best of our knowledge, this is the only study that reports the incidence of moist wound environment from treatment of wounds with plant material.

The regenerative effect of of Costus afer stem juice extract is evidenced by its healing outcomes. Groups D and E treated with Costus afer stem juice extract had randomly organised dermal fibres like that of normal uninjured tissue which is a characteristic of dermal regeneration. In addition, the presence of hair follicles in group D, treated only on the first day with Costus afer paste, is also indicative of the regenerative capacity of Costus afer stem juice $[47,48]$.

However, the effect of the moist wound environment on the healing process might have been augmented by the presence of pro-healing molecules and minerals in the extract. Studies have shown that alkaloids and quinones increase the rate of re-epithelialization, thereby reducing the healing time. High deposition and organization of collagen fibres in the dermis were also observed in wounds treated with these molecules as well as those treated 
with triterpenes [40,41,49-52].The presence of calcium, magnesium, copper, potassium, phosphorus and manganese in the extract may act to regulate the activities of enzymes and growth factors in the wound environment. Copper has been reported to significantly enhance angiogenesis, re-epithelialization, and collagen organization $[38,43,53-$ 56]. However, its effectiveness in enhancing the healing process may also be due to its effects at the nuclear or molecular level which is not investigated in this study.

It is suggested that the delay in healing time for group E treated for 7 days with Costus afer stem juice extract was due to the development of invading fibrous tissues which deepened the extent of the injury. Therefore, on falling of the scab and withdrawal of treatment, the healing process had to start from resorption of the fibrous tissue and regeneration of the invaded tissue, thereby extending the healing time. The complication that led to the formation of the invading fibrous tissue in group E, may be due to the hyperactivity of the chemical constituents of the extract which could have been provided in excess from daily application of the extract. The hypothesis is that continuous extraction of tissue fluid by the extract became injurious to surrounding cells and tissues, which tried to protect itself by forming a demarcating fibrous tissue to repair and seal the injury. Ironically, the extract also contained molecules and minerals such as copper, alkaloids, quinones, lignans and manganese that promote fibrous tissue formation, thereby reinforcing the process to invade deeper tissues. This hypothesis is born from the observation that this process of fibrous invasion regressed on treatment withdrawal and, when the scab fell off leaving an open moist wound, the healing process gradually shifted from repair to regeneration of the skin. In addition, no such fibrous tissue was observed in group $\mathrm{D}$, treated only on the first day with Costus afer paste. Therefore, with little refinement to Costus afer stem juice extract, it may present an ideal topical treatment for management of skin wounds [6].

\section{Conclusions}

The findings from this study have shown that treatment of wounds with Costus afer stem juice extract provides an open moist wound environment through most of the healing process. This provision, together with the wound healing properties of its molecular and mineral constituents drives the healing process towards faster regeneration of skin tissue as evidenced in the reduced healing time, dermal organization and development of hair follicles in the healed tissue. The ability of Costus afer stem juice extract to maintain an open moist wound without infection is noteworthy, as it could provide an ideal topical treatment for wound healing.

\section{References}

1. Mendonca RJ de, Coutinho-Netto J (2009) Cellular aspects of wound healing. Anais Brasileiros de Dermatologia 84: 1-6.

2. Velnar T, Bailey T, Smrkolj V (2009) The wound healing process: an overview of the cellular and molecular mechanisms. J Int Med Res 37: 1528-1542.

3. Atiyeh BS, loannovich J, Al-amm CA, El-musa KA (2002) Management of Acute and Chronic Open Wounds: The Importance of Moist Environment in Optimal Wound Healing. Curr Pharm Biotechnol 3: 179-195.

4. Wells C, Power L (2008) Principles of Wound Healing. In: Skin and Wound Care Manual. St. Clare's Mercy Hospital, Eastern Health

5. Singer AJ, Dagum AB (2008) Current Management of Acute Cutaneous Wounds. N Engl J Med 359: 1037-1046.
6. Korting HC, Schollmann C, White RJ (2011) Management of minor acute cutaneous wounds: importance of wound healing in a moist environment. J Eur Acad Dermatol Venereol 25: 130-137.

7. Bolton LL (2004) Moist Wound Healing from Past to Present. In: Rovee DT, Maibach HI, editors. The Epidermis in Wound Healing. 1st ed. Florida: CRC Press p. 89-100.

8. Gantwerker EA, Hom DB (2012) Skin: Histology and physiology of wound healing. Clin Plast Surg 39: 85-97.

9. Zhai $\mathrm{H}$, Maibach $\mathrm{HI}$ (2004) Occlusive and Semipermeable Membranes. In: Rovee DT, Maibach HI, editors. The Epidermis in Wound Healing. 1st ed. Florida: CRC Press p. 103-110.

10. Broughton II G, Rohrich RJ (2005) Wounds and Scars. Selected Readings in Plastic Surgery10: 1-56.

11. Moon K (2013) Clinical Guidelines (Nursing) : Wound care [Internet]. The Royal Children's Hospital Melbourne.

12. Thakur R, Jain N, Pathak R, Sandhu SS (2011) Practices in wound healing studies of plants. Evidence-based complementary and alternative medicine 438056 .

13. Fern K (2014) Costus afer - useful tropical plant [Internet]. Usefule Tropical Plant Database 6-8.

14. Anyasor GN, Onajobi FD, Osilesi O, Adebawo O (2014) Proximate composition, mineral content and in vitro antioxidant activity of leaf and stem of Costus afer (Ginger lily). J Intercult Ethnopharmacol 3: 128-134.

15. Akpabio UD, Udo UE, Akpakpan AE (2012) Evaluation of phytochemical, proximate and mineral element composition of stem of Costus afer (Bush cane). Asian Journal of Plant Science and Research 2: 607-612.

16. Akpantah $\mathrm{AO}$, Akpan $\mathrm{U}$, Eluwa $\mathrm{MA}$, Isamoh $\mathrm{TE}$, Udonkang $\mathrm{M}$, et al (2016) Blood Parameters and Spleen Histology Following Chronic Consumption of Ethanolic Extract of Costus afer Stem and Juice on Albino Wistar Rats. Br J Med Med Res 13: 1-10.

17. Dorsett-martin WA (2004) Rat models of skin wound healing: A review. Wound Repair Regen 12: 591-599

18. Sotocina SG, Sorge RE, Zaloum A, Tuttle AH, Martin LJ, et al. (2011) The Rat Grimace Scale: A Partially Automated Method for Quantifying Pain in the Laboratory Rat via Facial Expressions. Mol Pain 7: 1744-8069.

19. OECD. Test Guideline 425Acute Oral Toxicity - Up-and-Down Procedure. 2001.

20. Ekwueme FN, Nwodo OFC, Joshua PE, Nkwocha C, Eluka PE (2015) Qualitative and Quantitative Phytochemical Screening of the Aqueous Leaf Extract of Senna mimosoides: Its Effect in in vivo Leukocyte mobilization induced by inflammatory stimulus. Int J Curr Microbiol App Sci 4: 1176-1188.

21. Vogel Al (1989) Atomic Absorption and Flame Emission Spectroscopy. In: Jeffery GH, Basseyy J, Mendham J, Denney RC, editors. Vogel's Textbook of Quantitative Chemical Analysis. 5th Ed. England: Longman Scientific and Technical 779-815.

22. Bancroft JD, Layton C. (2013) The Hematoxylins and eosin. In: Suvarna SK, Layton C, Bancroft JD, editors. Bancroft's Theory and Practice of Histological Techniques. 7th ed. China: Churchill Livingstone.

23. Burkill HM. Costus afer Ker-Gawl. [family Costacae] [Internet]. JSTOR Global plants. JSTOR; 1985. 
24. Aweke G. Costus afer Ker Gawl [Internet]. Schmelzer GH, GuribFakim A, editors. Wageningen, (2017) Netherlands: PROTA (Plant Resources of Tropical Africa / Ressources végétales de l'Afrique tropicale); p. 4-7.

25. Omokhua GE (2011) Medicinal and Socio-Cultural Importance of Costus Afer (Ker Grawl) in Nigeria. African Research Review 5: 282287

26. Ejiogu MC, Ezeibekwe IO, Egbucha KC (2016) Antifungal activity of the plant costus afer extract on yam (dioscorea species) rot pathogen in owerri. south-east nigeria. Journal of Botany and Research 1: 1-6.

27. Uchegbu RI, Akalazu JN, Ibe CO, Ahuchaogu AA, Amadikwa CU (2016) Chemical Composition of the Stem Extract of Costus afer Bush Cane ) and Its Antimicrobial Activity. Br J Pharm Res 10: 1-9.

28. Ijioma SN, Nwosu CO, Emelike CU, Okafor Al, Nwankwo AA (2014) Antinociceptive Property of Costus afer Ker Stem Juice and Ethano Leaf Extract in Albino Rats. Comprehensive Journal of Medical Sciences. 2: 14-19.

29. Ukpabi CF, Agbafor KN, Ndukwe OK, Akuagwu A, Nwachukwu SN (2012) Phytochemical Composition of Costus Afer Extract and Its Alleviation of Carbon Tetrachloride-induced Hepatic Oxidative Stress and Toxicity. International Journal of Modern Botany 2: 120-126.

30. Tonkiri A, Essien EB, Akaninwor JO, Ogbomade RS (2015) Protective Effect of Costus afer on Lipid Profile and Hepatic Damage in Ethanol - Induced Liver Cirrhosis in Rats. Int J Biochem Res Rev 6: 53-61.

31. Tchamgoue AD, Tchokouaha LRY, Tarkang PA, Kuiate J, Agbor GA (2015) Costus afer Possesses Carbohydrate Hydrolyzing Enzymes Inhibitory Activity and Antioxidant Capacity In Vitro. Evidence-based complementary and alternative medicine : eCAM. 987984.

32. Goodies ME, Emmanuel IE, Earnest EO (2015) Evaluation of the Ulcerogenic potential of the Aqueous extract of Spondias mombin and Costus afer. International Journal of Advances in Pharmacy, Biology and Chemistry 4: 282-286.

33. Luna-vázquez FJ, Ibarra-alvarado C, Rojas-molina A, Rojas-molina I, Zavala-sánchez MÁ (2013) Vasodilator Compounds Derived from Plants and Their Mechanisms of Action. Molecules 18: 5814-5857.

34. Ngameni B, Fotso GW, Kamga J, Ambassa P, Abdou T, et al. (2013) 9- Flavonoids and Related Compounds from the Medicinal Plants of Africa. Medicinal Plant Research in Africa 301-350.

35. Suckling L. Does salt water really heal open wounds? [Internet]. Life \& Style. 2016

36. Ehrlich SD (2015) Phosphorus [Internet]. University of Maryland Medical Center, USA.

37. Cherney K (2017) Potassium [Internet]. Healthline.

38. Higdon J, Drake V, Delage B (2014) Magnesium [Internet]. Linus Pauling Institute.

39. Swezey L (2015) Nutrition and Wound Healing: Micronutrients Required for Wound Healing-Wound Educators.com [Internet].
40. Sandjo LP, Kuete V (2013) 4-Triterpenes and Steroids from the Medicinal Plants of Africa. In: Medicinal Plant Research in Africa 135-202.

41. Eyong KO, Kuete V, Efferth T (2013) 10-Quinones and Benzophenones from the Medicinal Plants of Africa. In: Medicinal Plant Research in Africa 351-391.

42. Mbaze LM, Lado JA, Wansi JD, Shiao TC, Chiozem DD, et al. (2009) Oxidative burst inhibitory and cytotoxic amides and lignans from the stem bark of Fagara heitzii (Rutaceae). Phytochemistry 70: 14421447.

43. Kornblatt AP, Nicoletti VG, Travaglia A (2016) The neglected role of copper ions in wound healing. J Inorg Biochem 161: 1-8.

44. Guo S, Dipietro LA (2010) Factors affecting wound healing. J Dent Res 89: 219-229.

45. Kumar S, Leaper DJ (2005) Classification and management of acute wounds. Surgery 23: 43-47.

46. Davis CP (2017) Dehydration: Symptoms, Signs, Headache, Treatment, Effects [Internet]. EmedicineHealth.

47. Yannas I V (2015) Regeneration of Skin. In: Tissue and Organ Regeneration in Adults. 2nd ed. New York: Springer; 93-137.

48. Stocum DL. Regenerative Medicine of Skin, Hair, Dental Tissues and Cornea. In: Regenerative Biology and Medicine. 2012. p. 63-98.

49. Nesterova YV, Povetieva TN, Suslov NI, Zhdanov VV, Hrichkova TY, et al (2012) Regeneratory characteristics of complex extract and isolated diterpene alkaloids of Aconitum baikalense. Bull Exp Biol Med 152: 439-443.

50. Mahibalan S, Stephen M, Nethran RT, Khan R, Begum S (2016) Dermal wound healing potency of single alkaloid (betaine) versus standardized crude alkaloid enriched-ointment of Evolvulus alsinoides. Pharm Biol 54: 2851-2856.

51. Tsala DE, Amadou D, Habtemariam S (2013) Natural wound healing and bioactive natural products. Phytopharmacology 4: 532-560.

52. Swamy HMK, Krishna V, Shankarmurthy K, Rahiman BA, Mankani KL, et al. (2007) Wound healing activity of embelin isolated from the ethanol extract of leaves of Embellia ribes Burm. J Ethnopharmacol 109: 529-534.

53. Banai S, Haggroth L, Epstein SE, Casscells W (1990) Influence of extracellular magnesium on capillary endothelial cell proliferation and migration. Circulation research 67: 645-650.

54. Kitch S (2014) Copper Accelerates Skin Healing [Internet]. CopperMe.

55. Higdon J, Drake VJ (2010) Manganese [Internet]. Linus Pauling Institute

56. Higdon J, Drake VJ, Delage B (2014) Phosphorus [Internet]. Linus Pauling Institute. 